\title{
Second-Generation Semiology and Detotalization
}

Original Study

Tyler James Bennett

Palacký University Olomouc, Department of General Linguistics

\begin{abstract}
The fashionable disavowal of structural semiology as logocentric is easily countered by a review of the important innovations of second-generation semiology, spearheaded by Jacques Derrida, Roland Barthes, and Jacques Lacan. The scope of Saussurean semiology is hampered only by its reliance upon alphabetic language and presence grounded in the voice; the assertion that semiology is a part of linguistics, rather than the reverse, does not reject the existence of nonlinguistic meaning; wordplay and textual experimentation are no mere stylistic ornamentation, but are on the contrary the key strategy of second-generation semiology for exposing the limitations of language. All three of these writers rely upon the glossematics of Louis Hjelmslev for the articulation of the concrete, non-logocentric object of general linguistics - his stratification of the Saussurean sign provides the centerpiece for the synthetic theoretical model introduced here.
\end{abstract}

Keywords: logocentrism; black pyramid schema; Peirce-Hjelmslev hybrid

\section{INTRODUCTION}

Detotalization describes the tradition of semiotics which takes psychoanalysis, ideology critique, and structural semiology as its major theoretic coordinates. Interest in these coordinates has declined against the ascent of the semiotics of Charles Peirce, the two approaches are sometimes construed as irreconcilable, but the recently published and defended dissertation Detotalization and Retroactivity: Black Pyramid Semiotics (Bennett 2021) seeks to integrate Peirce to the coordinates of detotalization. The black pyramid schema is a picture of the Peirce-Hjelmslev hybrid, where Peirce is integrated to detotalization. Retroactivity is the bridge concept for this task. The current article is a redacted version of the first chapter of the dissertation, with some additions made for clarification. The article deals with the role of second-generation semiology in the conception of the Peirce-Hjelmslev hybrid, and the development of the notion of metalinguistic retroactivity.

Specific modifications were made to Saussurean semiology by the members of what is called second-generation semiology. Some of the changes were made with the stated intent to widen the scope of application of semiology to non-linguistic signs, but without introducing a referent or imposing a realistic orientation to the object. Roland Barthes and Jacques Derrida were specifically interested in extending semiology beyond the confines of language, and a major inspiration for them both in this project was the stratification of the sign into form and substance, an idea introduced by Louis Hjelmslev in his Prolegomena to a Theory of Language (1953 [1943]). The stratification is the veritable backbone of the black pyramid schema (Figure 1). It adds additional layers, or strata, to the division of the signifier (expression) from the signified (content).

The form of the signifier and the form of the signified are on the inside, the substance of the signifier and the substance of the signified on the outside. In Figure 1, form is indicated by ' $f$ ' and substance is indicated by ' $s$ ', signifier is indicated by 'sr' and signified is indicated by 'sd'. Both the idea of stratification, as well as the labels of form and substance, were systematized by Hjelmslev in "La stratification du langage" (Hjelmslev 1954), but he explains there how the "double distinction" of the parts 


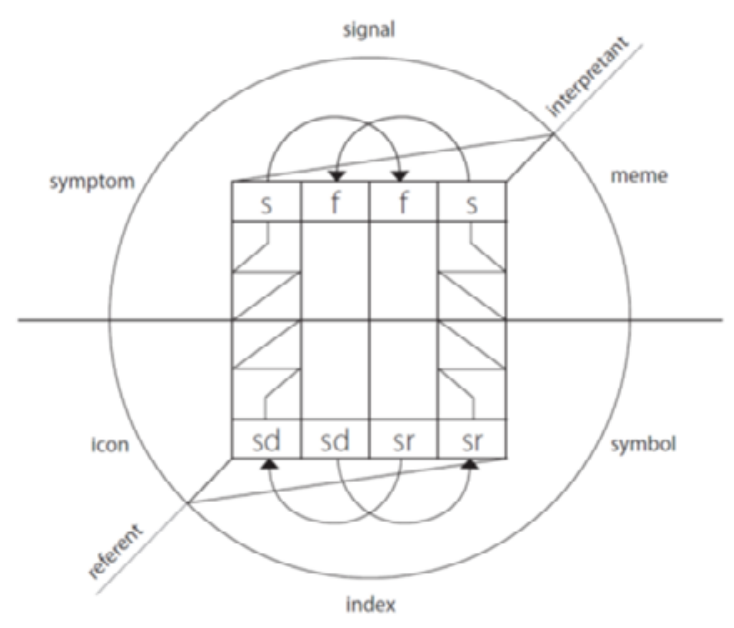

Figure 1: Black pyramid schema

of the sign into form and substance in fact derives originally from Saussure himself (Hjelmslev 1954, 163). ${ }^{2}$

The sign function for Hjelmslev strictly pertains to the relation between the parts of the sign at the level of form alone, not at the level of substance. This is conveyed in the idea of presupposition, a notion which is described from pages 23 to 26 of the Prolegomena to a Theory of Language (1953 [1943]). As it is said there, the substance always presupposes the form. This means that there can be no substance without form, but there can be form without substance. This is what gives the sign function ultimate priority over the substance, and makes it the main interest of semiotics for Hjelmslev. This formalism departicularizes the sign, taking further the claim already from Saussure, that the signifier is not the phonological substance.

Émile Benveniste (1969, 1985 [1981]) coined the term second-generation semiology to designate the twentieth century descendants of Saussure, with emphasis upon those who discuss Louis Hjelmslev's stratification of the sign by form and substance. In their view, linguistics remains a principal theoretic coordinate of semiotics, and the object-referent is included within the model of the sign only by means of incompatibilities and inconsistencies at the level of the system of description (that is, at the level of language).

It is important to note that substance retains an important place in Hjelmslev - it is not interchangeable with the empirical matter of the referent, but is rather something like the outside of the inside. Substance remains within the descriptive system, but doubles the sign opposition into a nested layering, and the interplay between these layers is supposed to give indirect access to that which may really be outside. In this application, Hjelmslev's notion of presupposition is central: form is always presupposed by substance. Greimas and Courtés (1982 [1979], 243) include presupposition in their analytical dictionary, where again substance presupposes form, meaning that form always preceides substance, but they also include the idea of "reciprocal presupposition". Reciprocal presupposition suggests that form may also presuppose substance, and this idea is crucial. It is this reversal of the order of priority in presupposition that is the technical definition given for retroactivity. It is also the possibility of this reversal that distinguishes second-generation semiology from Saussure's semiology: for the latter, retroactivity was a mere possibility, but for the former, retroactivity is the main interest, and produces a textual methodology all its own. The reversal of direction in presupposition is indicated by the arrows at the upper level of Figure 1. The way that retroactivity produces an interpretant is an invention of Umberto Eco. The black pyramid schema itself is modeled on a diagram given by Umberto Eco (Eco 1979[1976], 51), and Eco is credited with inventing the so-called "Peirce-Hjelmslev hybrid" (see Genosko 2016, 17) by his theorization of the interpretant and by his challenge to the referential aspect of Peirce's object.

Derrida's critique of Saussure in Of Grammatology (1976 [1967]) does not reject the separation of langue and parole. On the contrary, Derrida says that Saussure does not go far enough in this procedure, and that the object-referent is covertly smuggled back in to Saussure (Saussure's semiology becomes logocentric) by means of his reliance upon phonological alphabetic language and the linguistic identity of the sender. Derrida unfurls somewhat the concrete object of linguistics, which is no longer any particular language, but a translinguistic, profound articulatory matrix, which is the precondition of all languages, and which he labels alternately as the trace and primordial différance. The matrix is only describable by means of de-centered arche-writing (French: archi-écriture; cf. Derrida 1976 [1967], 56, 57, 60, 61, 68, 69, 92, $109,110,112,125,128,140,228)$. The theorization of this kind of retroactive writing is the major contribution of second-generation semiology. The attention of the article is directed firstly upon the particulars of Derrida's critique of Saussure through discussion of Russell Daylight's What if Derrida was Wrong about Saussure? (2012 [2011]), and secondly to the Lacanian concept of retroactivity and its implementation in Derrida's notion of arche-writing. This is the first piece of the black pyramid schema. Later chapters of the dissertation explain its more advanced operations and applications outside of semiology.

Some other aspects of the black pyramid schema remain mysterious. For instance, Figure 1 does not precisely look like a pyramid. The pyramid is selected partially for some of its symbolic associations, such as a sign from an ancient civilization implying the advanced state of their knowledge of astronomy. Derrida and Lacan's appropriation of the Egyptian hieroglyph to signify

1 Special thanks to Tiia llus for helping to design the figures.

2 Special thanks to Eugenio Israel Chávez Barreto for exegesis of Hjelmslev. 
a universal but non-algebraic language is also intended here. But the real answer to the puzzle of the black pyramid is within some interspersed citations of the poetry of W. B. Yeats that appear in each chapter of the dissertation. The specific chapter upon which this article is based dwells at greatest length upon the writing style of retroactivity itself, which detotalization adopts in its semiotic application. The actual metaphysical inspiration of the black pyramid schema is raised briefly at the end of this article, but is only dealt with comprehensively in the fifth chapter of the dissertation.

\section{DETOTALIZING SEMIOLOGY}

When posing the question, "What is both the integral and concrete object of linguistics?" (Benveniste 1985 [1981] 230), Benveniste upholds the Saussurean dictum that linguistics is only one part of the broader semiology, or semiotics

It is therefore possible to conceive of a science which studies the role of signs as part of social life... We shall call it semiology (from the Greek, semeion, 'sign'). It would investigate the nature of signs and the laws governing them. Since it does not yet exist, one cannot say for certain that it will exist. But it has a right to exist, a place ready for it in advance. Linguistics is only one branch of this general science. (Saussure 1983[1915], 15-16)

The assertion that linguistics is only one part of a broader semiotics is meant to uphold that language is only one modality among a number, including sensory motor, affective, and emotional systems for example. This of course is true, but the statement has led to the misapprehension of the intent of the semiological approach. When the reverse claim is made, that rather semiotics is only one branch of linguistics, it can be interpreted to mean the opposite: that sensory motor, affect, etc., are subordinate to language, and language is the only semiosic modality that matters. A pivotal opening assertion of the dissertation is that this gets semiology all wrong

A key feature of the approach is that linguistics must remain the central theoretic coordinate exactly because of the tendency for language to eclipse other modalities of the sign. These other modalities are part and parcel to the concrete object of linguistics, which is itself beyond mere language, and second-generation semiology prescribes a very specific textual methodology for challenging the hold that language exerts on the sign, and freeing it to other modal expressions, which themselves may not be expressed by any tangible positivity in language, but which may nevertheless be approached by means of the trace, by de-centered arch writing, and by other retroactive strategies which are described throughout the dissertation

Although Benveniste in his article of 1981 (reprinted as a chapter 1985), includes Roland Barthes as a paramount representative of second-generation semiology,
Barthes expresses the extension of semiology somewhat differently than Benveniste does in the preceding citation. He appears to contradict both Benveniste and Saussure before him. Derrida labels the way in which Barthes contradicts them as the "Barthesian reversal" (1976 [1967], 52). In the early pages Elements of Semiology Barthes explains how linguistics, no matter the modality of the object of inquiry, remains the central coordinate of semiotics because:

the moment we go on to systems where the sociological significance is more than superficial, we are once more confronted with language. It appears increasingly more difficult to conceive a system of images and objects whose signifieds can exist independently of language: to perceive what a substance signifies is inevitably to fall back on the individuation of a language: there is no meaning which is not designated, and the world of signifieds is none other than that of language. (Barthes 1977[1964], 68)

At face value, this is merely a restatement of the linguistic turn; it is also consonant with the premise of critical theory, which is the idea of alienation. The subject is born into language - more simply, all cognition is constrained by language. Barthes' Elements can appear old-fashioned in this reading. He can be interpreted to simply be behind the times, behind the Peircean, iconic, embodiment, or schematic turns (Stjernfelt 2007, 72-75). He can also be read anthropocentrically, as if his purpose here were to reassert the significant privilege of language-capable species. An alternative reading is proposed, whereby Barthes here is actually of a piece with the others (Derrida, Eco, and even later Peircean cognitive and biosemiotics incidentally).

The Barthesian reversal challenges the naturalistic-romantic fallacy, that by simply labeling sensory motor affects, emotions, or environmental entities with concepts or terms from different philosophies or sign typologies, one may somehow recuperate these entities out from under their subordination to verbal language. Barthes was concerned that, in its laudable efforts to avoid logocentrism and anthropocentrism, semiotics might lose its defining feature, which precisely is the exclusion of the referent.

He does not reject the possibility of non-linguistic meaning; he does not deny the existence of parole, the external, and matter; what he does is, he reasserts that if one's goal is to make access to sensory motor emotions, affects, and environmental entities, or better yet to even begin to describe 'nonhuman meanings', the starting point remains within language, to attack language from inside. He parallels Derrida precisely in his observation that Saussure did not go far enough, in the isolation of langue-form from parole-substance. It is with all this in mind, that one should read Barthes, when he performs the 'Barthesian reversal' of Saussure's order of priority between semiology and linguistics: 
In fact, we must now face the possibility of inverting Saussure's declaration: linguistics is not a part of the general science of signs, even a privileged part, it is semiology which is a part of linguistics: to be precise, it is that part covering the great signifying unities of discourse. By this inversion we may expect to bring to light the unity of the research at present being done in anthropology, sociology, psychoanalysis and stylistics round the concept of signification. (Barthes 1977[1964], 68)

The full implications of this formulation, especially as they are drawn out by Jacques Derrida in Of Grammatology, have not been absorbed by the greater community of scholarship in semiotics. Note first that this re-prioritization of linguistics in semiotics is not an attempt to limit the array of possible objects of analysis, as if to say that non-linguistic objects cannot be considered signs, nor does it comprise any sort of statement about the capacity of species other than humans to perceive or to use signs. Rather it maintains that the priority of linguistics as theoretic coordinate of semiotics is crucial specifically for its nonlinguistic applications and for serving as metatheoretic cross-disciplinary organizer between them.

And here the argument addresses a different level: this linguistics Barthes has in mind, which remains the central theoretic coordinate of semiotics, is not precisely the linguistics of Saussure. As he formulates it, linguistics is expanded or extended and applied to the great signifying unities of discourse, and the extrapolation of early semiology to the so-called secondary semiotic/modeling systems depends on this misunderstood extension. "Even so, such language is not quite that of the linguist: it is a second-order language, with its unities no longer monemes or phonemes, but larger fragments of discourse referring to objects or episodes whose meaning underlies language, but can never exist independently of it" (Barthes 1977[1964], 11).

Derrida's Of Grammatology similarly extends the linguistic coordinate of Saussurean semiology by redefining the integral and concrete object of linguistics, not as the substance of any particular language, but as a translinguistic articulatory matrix. "Linguistics is not general as long as it defines its outside and inside in terms of determined linguistic models" (Derrida 1976[1967], 43). Derrida and Barthes both explicitly promote Louis Hjelmslev's stratification of the sign, as the diagrammatic key to the extension of semiology.

To repeat in the simplest possible manner, what is important about Hjelmslev's extension of Saussurean semiology is only that Hjelmslev underlines something that Saussure merely said, which is just that: the signifier is not the phonological substance, and its counterpart notion, if less easily conceived, that: the signified is not the concept in the brain of a particular person.

A problem that arises for Saussure's Course turns out to be that, although Saussure upholds that the signified is not the substance, he nevertheless privileges the acoustic sound as the exemplar of the signifier; more complicated, for Saussure the meaning of the sign remains with the language user or speaker/sender, in their linguistic identity.

But one can see here how, by endorsing the Hjelmslevian extension, Derrida is explicitly not calling for Saussure to account for the external object-referent in any literal fashion, especially not by including a dimension for it within the sign model itself, such as Peirce's index is presumed to do. By Derrida's thinking, this would merely impose a false center to the system of description, when the aim of the deconstruction is one of de-centering. In the view of second-generation semiology, which includes Derrida and Barthes but can also encompass Kristeva and Lacan, Saussure came very far in his theorization of the sign, especially in its strictly differential definition and attempted exclusion of the object-referent.

The paradoxical formulation is that, if one takes Saussure to the limit, and does away with the object-referent not only in name but also in methodology (if one excises the linguistic identity of the speaker/sender from the system of description entirely) the external inevitably breaks back into the description (later, in the form of the interpretant). This is the basis for certain textual and methodological procedures, whose inspiration in part derives from hermetic qabbala ${ }^{3}$. It is Derrida's reading of Saussure in Of Grammatology that initially lays out this possibility, but Derrida's reading of Saussure is not accepted unequivocally.

\section{WHAT IF DERRIDA WAS WRONG ABOUT SAUSSURE?}

Russell Daylight's book could just as well be titled "What if Derrida was Too Hard on Saussure, given that in Daylight's own words, it is really only that "Derrida's engagement with Saussure is fragmented, tangential, and implicit" (Daylight 2012[2011], 2), and not that Derrida was entirely wrong about Saussure. Daylight's specific argument is that Derrida gets Saussure wrong when he locates in Saussure the heritage of "classical semiology" (Daylight 2012 [2011], 19-32) and argues on this

\footnotetext{
3 Chapters three and four of the dissertation deal at greater length with the hermetic inspiration for the textual experimentalism found in much second-generation semiology. The relevance of qabbala for semiology, and the idea for how the immanent permutation of a closed set of terms may provide evidence for extra-systemic agents or entities, is expressed well by one late semiologist: "It is the rational dismissal of 'the' qabbalistic enterprise that is forced to take a metaphysical stance: ruling out on grounds of supposed principle what is in fact no more than a guiding 'empirical' hypothesis (that signal from 'outside the system' is detectable by numerical analysis of codes circulating within the system)" (Land 2019[2011], 592).
} 
basis (and others) that Saussurean semiology is logocentric. Daylight also understands the deeper intent of Derrida's reading of Saussure - which does indeed go beyond a mere appraisal of semiology as such - even though he does not agree with it. As he states: "Derrida acknowledges the progress of the Saussurean event which helps to loosen Western metaphysics, but at the same time, shows how this event falls back into the language it seeks to contest" (Daylight 2012[2011], 9).

Daylight's work underlines how Derrida amplifies the definitive features of Saussure's semiology, as discussed above. He acknowledges what Derrida says, which is "On that precise point, it is not a question of 'going beyond' the master's teaching, but of following and extending it" (Derrida 1976 [1967], 53), but Daylight still thinks the challenge to semiology has been taken too far. He is correct in this, but the fact remains that Derrida's charge of logocentrism against Saussure runs deeper than Daylight is interested to pursue.

Daylight's first chapter covers classical semiology, by which term he mostly means Aristotle but also includes Augustinus, in order to elucidate the differences between it, on the one hand, and Saussurean semiology on the other. Daylight finds that Derrida's accusation against Saussure betrays a disregard for these differences. It is important to summarize these issues here because, among other reasons, the definition of logocentrism depends on these Greek and Latin sources. The naïve understanding of logocentrism that may be called glottocentrism, is not under discussion here. Only the real logocentrism that asserts a bond between signified and object-referent (denotatum) is under discussion here, because it is only this of which Derrida accuses Saussure. Derrida's interrogation of classical metaphysics begins with a quotation from the opening few lines of Aristotle's On Interpretation:

Spoken words are the symbols of mental experience and written words are the symbols of spoken words. Just as all men have not the same writing, so all men have not the same speech sounds, but the mental experiences, which these directly symbolize, are the same for all, as also are those things of which our experiences are the images. (Aristotle: 16a, 2-4) in: Daylight (2012 [2011], 20)

For Daylight at least, the above fairly summarizes the meaning of logocentrism: the belief in a common substrate of thought shared by all people, independent of language. The substrate is reinforced by a natural relation between concept (signatum) and object-referent (denotatum). In Daylight's view, Derrida imparts upon Saussurean semiology this classical perspective, which in truth Saussure does not share. That is, Daylight's argument is that "Derrida posits a system of classical semiology in which a signans is opposed to a signatum, and in which the signatum can stand equally well for the concept or the thing" (2012[2011], 27) even though Saussure doesn't hold this, and Daylight very carefully shows how Saussure indeed does not ever assert an explicit bond between signified and object/referent. On the contrary, Saussure's whole point is to do just the opposite.

But the truth is that Derrida does not find logocentrism in Saussure in this obvious way. The logocentrism Derrida finds in Saussure is more insidious, and Daylight as much as admits this, while in other places still characterizing Derrida's account in a simplistic way. Derrida does not neglect the fact that, in Saussure's semiology, there is not meant to be any bond between thing (object-referent/denotatum) and concept (signified). This is not where Derrida finds logocentrism in Saussurean semiology. He finds it in the phonocentrism of Saussure, but the link between phonocentrism and logocentrism for Daylight remains unclear.

Derrida asserts that phonocentrism is essential to certain ancient and medieval theories of language. The only textual evidence that Derrida offers for such a classical phonocentrism is Aristotle's On Interpretation. However, this position is hardly disputable, if one allows dissenting positions to exist on the margin. Derrida also argues that these same theories display a logocentrism, which, in this context, is the existence of a sense or meaning prior to the derivation of linguistic signifiers. (Daylight 2012 [2011], 31)

Daylight does not deny the logocentric aspect of classical semiology. What he denies is the accusation of logocentrism against Saussurean semiology, because he claims that Derrida's accusation there rides entirely upon a conflation of phonocentrism (a charge which Daylight allows against Saussure) with logocentrism. While Daylight is correct that the one does not equate the other, he is wrong that Derrida's entire charge against Saussure rides upon this conflation.

\section{What Derrida mainly fails to demonstrate in his characterization of classical semiology is the logical or linguistic co-dependence of phonocentrism and logocentrism. For phonocentrism - as the privilege of speech over writing - and logocentrism - as the belief in mental experience without the need for language - are very different notions, even if they are found together. (Daylight 2012 [2011], 31)}

While Daylight is right that these are not the same thing, he seems not to take seriously the major idea in Of Grammatology, which is how being is falsely grounded in presence through the voice. What distinguishes phonocentric (alphabetical) languages from ideogrammatic ones for example, is that the former signify by reproducing the sounds of speech, whereas the latter do not. This in itself does not constitute logocentrism, as Daylight points out. The further, logocentric step is to then proceed to accept that the meaning or truth of a message is controlled by the speaker. When the voice of the 
spoken word is accepted as the guarantor of truth, an external factor is accepted into the sign as a discriminant parameter of its signification. In this way the sign is no longer purely differentially articulated, and this compromises its theoretic integrity. Thus, it is the phonological aspect of Saussure's conception of semiology, which imparts upon it a false center, a false certainty given by the presumed truth of the voice and the spoken word.

One important feature of this perspective is that, when speech and the voice are accepted as the guarantor of truth, they indirectly confer authority upon the linguistic identity of the speaker/sender and the community of language users. In this way, Derrida's critique of phonocentrism in semiology is the linchpin of the broader critique of different forms of logocentrism, such as ethnocentrism. In the latter, if signification is secured in the linguistic identity of the speaker/sender and the community of language users, those who are within the language group have privileged access to truth, whereas those who are outside that group are excluded from that truth and denied that authority. In this way, Derrida's critique of phonocentrism is a non-identical approach to the critique of ethnocentrism; i.e. an approach which does not attack specific ethnocentrisms per se, but which attacks the structure of ethnocentrism as such. This insight is the portal toward understanding how semiotics and deconstruction may provide a unifying vocabulary for many different progressive agendas deriving from poststructuralism. The point is that, although Saussure did not confuse the signified with the object-referent explicitly, Derrida is right that Saussure allows this confusion by grounding his analyses in phonological language, and Daylight does not take this link seriously.

The system of language associated with phoneticalphabetic writing is that within which logocentric metaphysics, determining the sense of being as presence, has been produced. [...] It is this logocentrism which, limiting the internal system of language in general by a bad abstraction, prevents Saussure and the majority of his successors from determining fully and explicitly that which is called "the integral and concrete object of linguistics". (Derrida 1976 [1967], 43)

Derrida cites Hjelmslev's Principes de grammaire générale of 1928 to defend his own claim that the spoken word should not precede or take priority over the written one within deconstruction (Derrida 1976 [1967], 57), and that the formalism of glossematics, just like that of grammatology, "operates at the same time thanks to Saussure and against him; that, as I suggested above, the proper space of grammatology is at the same time opened and closed by The Course in General Linguistics" (Derrida 1976 [1967], 58). At the same time, Derrida does not adopt the whole elaborate edifice of glossematics by any means. Hjelmslev gives the point of departure, but does not provide the key to the extension of semiology which
Derrida calls arche-writing, the broad term for which is retroactivity. Retroactivity only becomes important later.

The extension of semiology is bound up with the question: how to integrate the external without compromising the system of description by imposing a concrete object-referent? In other words, how is it possible to account for extra-semiotic reality without succumbing to logocentrism? Retroactivity and de-centered arche-writing are ways of dealing with the external. In this area, Roland Barthes is perhaps the actual hidden master.

\section{BARTHES' METALINGUISTIC RETROACTIVITY}

Barthes' Elements of Semiology and Derrida's Of Grammatology overlap significantly, in how they both privilege the Hjelmslevian stratification as the centerpiece of extended semiology, they both note its limitations, and they both follow Hjelmslev in their simultaneous embrace of Saussurean semiology and deposition of its actual limitations. "Hjelmslev has not thrown over Saussure's conception of language/speech, but he has redistributed its terms in a more formal way" (Barthes 1977[1964], 17). Barthes reiterates the position upheld by Saussure and repeated by Hjelmslev: the syntagm is always preceded by the paradigm. There can be no syntagm without there already being a paradigm, in the same way that there can be no substance without there already being a form. However, the important change that is brought by second-generation semiology is to theorize ways in which substance indeed may come before form, syntagm may come before paradigm, parole may come before langue. These are the ways of retroactivity, and in the chapter upon which this article is based, the focus is upon metalinguistic retroactivity. As indicated by the intersecting arrows connecting form and substance on the upper part of Figure 2, there are two kinds of retroactivity, which have an interactive and interdependent relationship. The connotative form of retroactivity is only briefly discussed here, as it comprises the main interest of the second chapter of the dissertation.

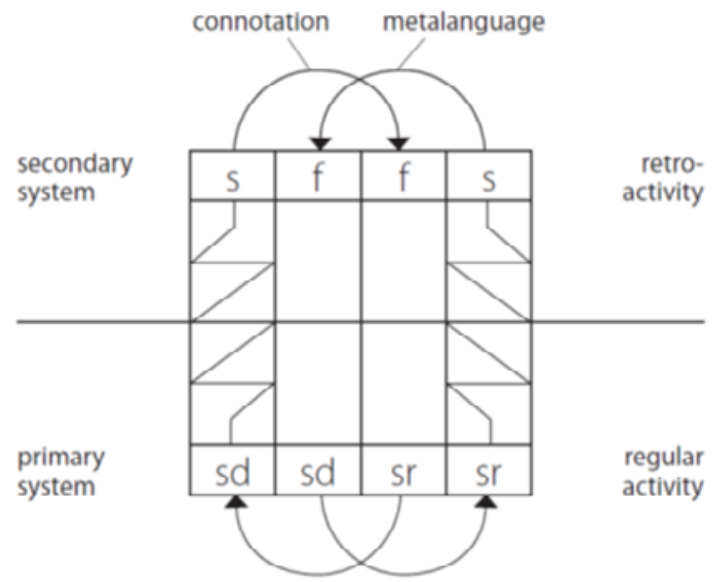

Figure 2: Two forms of retroactivity 
Barthes devotes some pages to the interaction of the two forms of retroactivity in a section near the end of Elements of Semiology, called "transgressions", which in several respects anticipates Derrida's notion of de-centered arche-writing.

III.3.7. Transgressions: [...] although such studies are only to be found here and there in a sketchy way, the whole of the phenomena in which one plane overlaps the other, in a way which is 'teratological' so to speak compared to the normal relations of the system and the syntagm. For the mode of articulation of the two axes is sometimes 'perverted', when for instance a paradigm is extended into a syntagm. There is then a defiance of the usual distribution syntagm/system, and it is probably around this transgression that a great number of creative phenomena are situated, as if perhaps there were here a junction between the field of aesthetics and the defections from the semantic system. (Barthes 1977[1964], 86)

Teratological overlappings are physical abnormalities and mutations - every deviation from the symbolic center begins from the retroaction of substance upon form. In this way, the critique of metalanguage undertaken by poststructuralism compounds metalinguistic stacking and its inevitable regress in the absence of a center ${ }^{4}$ In this way, non-identities and internal contradictions are precisely guided against high value targets - this kind of writing is signature, aligns with no explicit political agenda or philosophical position, and from the perspective of those unfamiliar with the theoretic coordinates under discussion, reads as completely opaque. The metalinguistic system in this sense is not merely the establishment of a higher-order language of description, but the transgression of lower-order ones as well. The critique of metalanguage itself is a function of the metalinguistic system.

Barthes, Derrida, and Lacan employ and rely on an even greater density of metalanguages than their precursors in structuralism; the regress of those metalanguages, the reversal of object language metalanguage dependency, and the inconsistencies that result, are repurposed for later usage. De-centered arche-writing as described by Derrida is writing in which the regress and its breakdown work against its parallel linear argumentation. Jerzy Pelc's disquisition on the theoretic foundations of semiotics also poses the problem of regress in a discipline whose main 'object' is

Metametalanguage, that is, a semiotic metalanguage of a second order. [...] And to which level belongs the language we have used just now to discuss semiotics (MS) with its separate branches and metametalanguages? What we used was a language of a yet higher level, a metametametalanguage, while the discussion itself belongs to a yet higher - metametatheoretical - level of semiotics (MMS). There can be more such levels as the present remarks demonstrate. (Pelc 1981, 22)

In the simplest possible sense here, when the topic of one's article is, for example, 'Martin Švantner's reading of Russell Daylight's reading of Jacques Derrida's reading of Roman Jakobson's reading of Ferdinand de Saussure', one begins to understand what is meant by 'the absurd regress of metalanguages and the loss of the object-referent'. On the same page, Pelc questions the "objective signs" (Pelc 1981, 22), the signs which Jakobson says refer to "items extraneous to language as such" (Jakobson 1996[1987], 103). To postulate either the top-level metalanguage or a foundational object language is, as Derrida describes it, to impart a false center to the system of description. The provisional center allows for the fixation of both object and metalanguage, but even so, "along the way we formulate fragmentary generalizations of a lower order and it is sometimes difficult to draw the line between semiotics(S) and semiotics(MS). Similarly, the border between semiotics (MS) and the higher levels of semiotics is sometimes harder to define" (Pelc 1981, 23). Without such closure, the attempt to organize metalanguages with respect to each other in even the simplest analysis leads to an inevitable, and at times absurd regress, in which elementary first order semiotic systems are already characterized as metametametalanguages.

\section{THE LIGHTNING TREE AND THE TORTOISE SHELL}

As a strategy for maintaining the coherent totality of their descriptive systems, Saussure and Hjelmslev both assert that the paradigm always precedes the syntagm, form takes priority over substance, language over speech. So, one way to conceive the detotalizing strategy of

4 The arch critical style is best summarized by Julia Kristeva: "Semiotics is therefore a mode of thought where science sees itself as (is conscious of itself as) a theory. At every instant of its production, semiotics thinks of its object, its instruments and the relation between them, and in so doing thinks (of) itself: as a result of this reflection, it becomes the theory of the very science it constitutes. This means that semiotics is at once a re-evaluation of its object and/or of its models, a critique both of these models (and therefore of the sciences from which they are borrowed) and of itself (as a system of stable truths). As the meeting-point of the sciences and an endless theoretical process, semiotics cannot harden into a science let alone into the science, for it is an open form of research, a constant critique that turns back on itself and offers its own auto-critique. As it is its own theory, semiotics is the kind of thought which, without raising itself to the level of a system, is still capable of modelling (thinking) itself" (Kristeva 1986[1968], 77, "Semiotics: A Critical Science and/or a Critique of Science"). 
retroactivity employed and described here, is the reversal of this order. This is the methodological key that, in distilled form, entails a kind of textual randomization.

As to the positive formulation of this arche-writing, Daniele Monticelli gives the examples of Juri Lotman's "translation of the untranslatable" (Monticelli 2008, 202), the "aleatory figure of non-being" and "possibility of an impossibility" (Monticelli 2008, 286), the "decision in a case of undecideability" (Monticelli 2008, 279), and bare statements of "constitutive incompleteness, openness and unrepresentability" (Monticelli 2008, 297). Meditation upon these paradoxes may give rise to non-identical wordplay. In the following citation, Monticelli translates some pieces from Lacan that show how Lacan uses a play on words to illustrate the philosophical idea, that only through discontinuities at the level of language may non-linguistic meanings be expressed.

We can use Lacan's wordplay with the Latin verbs separare and se parare to illustrate this idea. Both verbs are founded on the concepts of 'part' and 'partition', which clearly opposes the totality of the symbolic order. In fact, according to Lacan, it is through a separation (separare), a break in the signifying chain (or "the interval intersecting the signifiers") that the subject engenders itself (se parere). [...] If alienation marked the disappearance of being, separation gives rise to some being, which nevertheless remains evanescent and elusive, because it is from the area of the unborn - the unrealized - that the constitutive lack of the subject comes to inhabit the symbolic order as the irruption of something extraneous: "discontinuity, then, is the essential form in which the unconscious first appears to us as a phenomenon". (Monticelli 2008, 80; emphasis: D.M.)

The wordplay characteristic of some second-generation semiology is not mere ornamentation to something that could otherwise be captured in more conventional language. On the contrary, this wordplay is the main event. Elements of Semiology does not merely describe the transgression of the metalinguistic secondary semiotic system, but also enacts it, in its hyper-dense metatheory and its emphasis on contradictions within the assortment of metalanguages of which it treats. In the same way, Derrida's deconstruction does not merely describe the dual movement of his arche-writing.

The event-moment announced by Derrida, in his address inaugurating poststructuralism at The Languages of Criticism and the Sciences of Man symposium held at the Milton S. Eisenhower Library from October 18 to 21, 1966 with the infamous "Structure, sign, and play in the discourse of the human sciences" 5 (Derrida 2002 [1967], 278-294), denotes not just that moment, but also that of some deconstructed eschatology, within which de-centered arche-writing becomes the talisman of protection against the depredations of the accelerating alienation of technocapital. "Henceforth, it was necessary to begin thinking that there was no center, that the center could not be thought in the form of a present-being, that the center had no natural site, that it was not a fixed locus but a function, a sort of non-locus in which an infinite number of sign substitutions came into play" (Derrida 2002[1967] 354). One may begin to understand arche-writing here by reading Derrida's statement 'the center could not be thought' as an unintended allusion to W.B. Yeats' poem "The Second Coming", where the line is: "The center cannot hold/Mere anarchy is loosed upon the world" (Yeats 1919 in Finneran 1996 [1983], 187). There is no explicit allusion to Yeats by Derrida. The allusion is imputed retroactively.

The Yeats allusion invokes firstly the necessity of figurative (in this case poetic) language in retroactivity; secondly, it asserts the urgency of the event-moment, and the source of what Derrida calls its exigency: writing long ago replaced speech as the dominant form of human communication, but the consequences of this perceptual-modal shift become manifest only now.

Here there is a kind of question, let us still call it historical, whose conception, formation, gestation, and labor we are only catching a glimpse of today. I employ these words, I admit, with a glance toward the operations of childbearing - but also with a glance toward those who, in a society from which I do not exclude myself, turn their eyes away when faced by the as yet unnameable which is proclaiming itself and which can do so, as is necessary whenever a birth is in the offing, only under the species of a nonspecies, in the formless, mute, infant, and terrifying form of monstrosity. (Derrida 2002 [1967], 370)

In other words, the passage alludes to far more than just the literary transgression incumbent upon the event-moment. The political dimension is also invoked, which Derrida describes as the birth pangs of the event-moment, and is signaled once again by an apocryphal allusion to the poetry of W.B. Yeats, this time to his Poem "Easter, 1916" (Finneran 1996[1983], 180). The allusion is specifically to the recurring line from the poem: "A terrible beauty is born". The poem describes the feelings of its author on hearing news of the Irish Nationalist Easter Rising against British rule. The British responded to the uprising by executing the Irish republican leaders for treason. Yeats, when saying that "A terrible beauty is born", foresaw that the result of these executions would be the reinvigoration of the Irish nationalist home rule movement.

But the transgressive exigency of the event-moment goes beyond politics as well. The prognostic quality of Yeats' lines is underscored by means of another

5 «La structure, le signe et le jeu dans le discours des sciences humaines ». The paper was published in: L'écriture et la différence. Paris: Éditions du Seuil, 1967, 409-429 (Chapter X) (cf. Derrida 1993 [1967]). 
apocryphal allusion by Derrida, this time to "The Second Coming". Derrida writes, "By a slow movement whose necessity is hardly perceptible, everything that for at least some twenty centuries tended toward and finally succeeded in being gathered under the name of language is beginning to let itself be transferred to, or at least summarized under, the name of writing" (Derrida 1976 [1967], 7). It was already clear at the time of his authorship that this line refers to the telecommunications boom, and that when Derrida predicts the replacement of speech by 'writing', what he foresaw was the terrible beauty of what is now called information technology. The relevant stanza from Yeats' poem is this:

The darkness drops again; but now I know

That twenty centuries of stony sleep

Were vexed to nightmare by a rocking cradle,

And what rough beast, its hour come round at last, Slouches towards Bethlehem to be born?

(Yeats 1919 in Finneran 1996[1983], 187)

Twenty centuries of course refers to the birth of Christ and its obvious meaning in the stanza is the biblical prophecy of the resurrection, however in the context of second-generation semiology and Of Grammatology, the answer to the questions: what rough beast is about to be born, what terrible beauty is about to be born, and just what is this epoch-defining event, should not be sought in history or biography, but in linguistics and semiotics.

In his "The agency of the letter in the unconscious or reason since Freud" ${ }^{\prime \prime}$, Lacan touches on all of the principal themes discussed in this article so far. He raises the critique of metalanguage, the regress of the hierarchy of metalanguages and object languages, the attempted bracketing of the referent and its covert phonological reappearance in Saussurean semiology, the hermetic aspect of second-generation semiology, and the interdependence of metalinguistic retroactivity with connotation-ideology. In the following passage, Lacan's namesake for obscurity and wordplay is clearly illustrated. But it is just this feature which is the indispensable exigency of the event-moment.

For even broken down into the double spectre of its vowels and consonants, it can still call up with the robur and the plane tree the significations it takes on, in the context of our flora, of strength and majesty. Drawing on all the symbolic contexts suggested in the Hebrew of the Bible, it erects on a barren hill the shadow of the cross. Then reduces to the capital $Y$, the sign of dichotomy which, except for the illustration used by heraldry, would owe nothing to the tree however genealogical we may think it. Circulatory tree, tree of life of the cerebellum, tree of Saturn, tree of Diana, crystals formed in a tree struck by lightning, is it your figure that traces our destiny for us in the tortoise-shell cracked by the fire, or your lightning that causes that slow shift in the axis of being to surge up from an unnamable night into the Evravta [one in all] of language? (Lacan (2005 [1977], 117-118) ${ }^{7}$

There is no direct discussion of the qabbala in this work by Lacan, but the retroactive strategy here is to make the correlation even in the absence of a causal link. In the same way as pairing Yeats with Derrida, the serendipitous connection leads to a more important association because of its apocryphal status. In the quote from Lacan, the free associative chain moves from the natural linguistic variance of (tree), through its paradigmatic associative axis (flora), to its symbolic associations. The crucifixion coincides with the first letter of the tetragrammaton $(\mathrm{YHVH})$ suggesting the element of fire, which later cracks the tortoise shell, as fire is associated with the suit of wands of the Tarot. The switch to the second person singular 'you' is addressed to the tree split by lightning, which is also now the tree of life of the qabbala, the ten spheres or sephiroth of which provide the organization of the Tarot deck, the four suits of wands, cups, swords, and disks corresponding to the elements fire, water, air, and earth. The movement from the lowest sephira on the tree of life (Malkuth), to the highest sephira (Kether) represents the alchemical process of transubstantiation, analogous to the process of sublimation in psychoanalysis, and abstracted to the phylogenetic level of human evolution, from sensory motor emotion and affect, toward language, and beyond. The tortoise shell cracked by fire was used in China three thousand years ago as a form of prognostic divination; this is allegedly the origin of the Chinese book of changes, or I Ching. "What this structure of the signifying chain discloses is the possibility I have [...] to use it in order to signify something quite other than what it says" (Lacan (2005[1977], 117-118).

Dream interpretation, I Ching, and Tarot, are used in the fourth chapter of the dissertation in order to illustrate retroactivity in a substantialized, non-textual format. It is argued that the retroactive tactic for fighting logocentrism - so well expressed by second-generation semiology - has precursors in some of these hermetic traditions, and that the hermetic aspect is instructive not only for developing a robust retroactivity, but also for contextualizing the stigma which semiotics sometimes accrues, and for distancing semiotics from the bogus marketing campaigns and social initiatives with which it has sometimes become associated, which seek to borrow from its legitimacy without being accountable to the origins of its

6 One should notice that this refers to an original intervention made by Jacques Lacan, under the title "L'instance de la lettre dans l'inconscient", on 9 May, 1957, in the Amphithéâtre Descartes of the Sorbonne, Paris, at the request of the Philosophy Group of the Fédération des étudiants ès Lettres. Written version in French see Lacan 1966[1957].

7 Footnotes 17, 18, and 19 to pages 117-118 of Lacan (2005[1977]) are also worth reading. 
dangerous mystique. This topic falls under the heading of signomancy, and for more information the inquisitive reader should refer to the full text of the dissertation.

\section{CONCLUSION}

As indicated by Figure 2, metalanguage is only one out of two forms of retroactivity, the second one being connotation. The precise definition of connotative retroactivity is given in the second chapter of the dissertation, and the major argument there follows directly upon the argument of the preceding: extant Marxist literary semiotics fails to recognize the importance of metalinguistic retroactivity - it fails to demarcate the place within the system for so-called de-centered arche-writing. All projects of detotalization must proceed with consideration of this signature literary style. While the two forms of retroactivity have the titles of metalanguage and connotation in the chapter upon which this article is based, the respectively transgressive and ideological character of the opposed systems is a feature of their application in each subsequent chapter of the dissertation as well. The search for equivalent vocabulary for these two terms, from the fields of Marxist literary criticism, Umberto Eco's interpretative semiotics, psychoanalysis, and Peircean cognitive and biosemiotics, is what occupies of the rest of the work. The greatest and most fruitful challenge is to show how this de-centered style is also a concern for Peircean cognitive and biosemiotics. The argument of the fifth chapter of the dissertation is that the justification for this arche-writing can also be found even within the most scientific semiotics, such as within the works of Terrence Deacon. The details of this argument however are long and difficult, and must be consulted directly in the full-length text.

\section{REFERENCES}

Barthes, R., 1977 [1964]. Elements of Semiology. (Trans.: Lavers, A., Smith, C.) New York: Hill and Wang. [Eléments de sémiologie. Communications 4, 91-135].

Benveniste, É., 1969. Semiologie de la langue. Semiotica 1(1), 1-12.

Benveniste, É., 1985[1981]. The semiology of language. (Trans.: Ashby, G., Russo, A.) In: Innis, R. (Ed.), Semiotics: An Introductory Anthology. Bloomington: Indiana University Press, 228-246 [Semiotica, supplement 37(1), 5-23].

Daylight, R., 2012[2011]. What if Derrida was Wrong About Saussure? Edinburgh: Edinburgh University Press.

Daylight, R., 2012. The difference between semiotics and semiology. Gramma: Journal of Theory and Criticism 20, 37-50

Genosko, G., 2016. Critical Semiotics: Theory, From Information to Affect. London: Bloomsbury.

Greimas, A. J., Courtés, J., 1982[1979]. Semiotics and Language: An Analytical Dictionary. (Trans.: Crist, L. et al.) Bloomington: Indiana University Press
[Semiotique: dictionnaire raisonne de la theorie du langage. Paris: Hachette].

Hjelmslev, L., 1953 [1943]. Prolegomena to a Theory of Language. (Trans.: Whitfield, F. J.) Baltimore: Waverly Press [Omkring sprogteoriens grundlæggelse. $\mathrm{K} \varnothing$ benhavn: Bianco Lunos bogtrykkeri].

Hjelmslev, L., 1954. La stratification du langage. Word $10(2 / 3), 163-188)$.

Land, N., 2019[2011]. Fanged Noumena: Collected Writings 1987-2007. Cambridge: Urbanomic.

Monticelli, D., 2008. Wholeness and its Remainders: Theoretical Procedures of Totalization and Detotalization in semiotics, philosophy and politics. Tartu: Tartu University Press.

Pelc, J., 1981. Theoretical foundations of semiotics. American Journal of Semiotics 1(1/2), 15-45.

Saussure, F. de, 1983[1915]. Course in General Linguistics. (Eds.: Bally, Ch., Sechehaye, A.; trans.: Harris, R.) London: Duckworth.

Stjernfelt, F., 2007. Diagrammatology: An Investigation on the Borderlines of Phenomenology, Ontology, and Semiotics. Dordrecht: Springer

Yeats, W. B., 1996 [1989]. The Collected Poems of W. B. Yeats. (Ed.: Finneran, R. J.) New York: Simon \& Schuster Inc.

Return to front page $\uparrow$ 